\title{
Updated checklist of Hemerobiidae (Neuroptera) from Brazil and new distributional records in the Neotropical Region
}

\author{
Rogéria Inês Rosa LARA ${ }^{1 *}$; Nelson Wanderley PERIOTO' ${ }^{1,2}$ \\ ${ }^{1}$ Agência Paulista de Tecnologia dos Agronegócios, Polo Regional Centro Leste, Av. Bandeirantes, 2419, CEP 14030-670, Ribeirão Preto, SP, Brazil. \\ ¿2Universidade Estadual Paulista "Júlio de Mesquita Filho", Faculdade de Ciências Agrárias e Veterinárias, Programa de Pós-graduação em Agronomia (Entomologia Agrícola), Via de \\ Acesso Prof. Paulo Donato Castellane, s/n, CEP 14888-900, Jaboticabal, SP, Brazil. \\ * Corresponding author. E-mail: rirlara@yahoo.com.br
}

\section{ABSTRACT}

Hemerobiidae (Insecta, Neuroptera) is a cosmopolitan clade that comprises about 600 described species distributed into 26 genera. Since the publication of revisions to Hemerobius, Megalomus, Nusalala and Nomerobius, new records have been added in literature and taxonomic modifications have occurred at the genus level. The aim of this study was to update a checklist of Hemerobiidae species from Brazil and of specimens deposited at Coleção de Invertebrados do Instituto Nacional de Pesquisa da Amazônia (INPA), Manaus, Brazil; in order to summarize the geographical data of species in Brazilian states and in the Neotropical Region and to present new distributional data. The INPA collection holds 19 nominal species $(55.2 \%$ of the all specimens identified at species level) of hemerobiids into eight genera and six subfamilies, mainly from the Neotropical Region; the remaining studied specimens were identified to the genus level. Megalomus marginatus is reported for the first time in Brazil and Nusalala dispar in Ecuador. Moreover, ten new records for the Brazilian states are presented: two to Nusalala tessellata and Hemerobius, and one each to Megalomus impudicus, Notiobiella maculata, Sympherobius ariasi, Megalomus, Nusalala and Sympherobius.

KEYWORDS: Hemerobius, INPA, Megalomus, Nomerobius, Nusalala.

\section{Checklist dos Hemerobiidae (Neuroptera) do Brasil e novos registros de distribuição para a Região Neotropical}

\section{RESUMO}

Hemerobiidae (Insecta, Neuroptera) é um clado cosmopolita com cerca de 600 espécies descritas e distribuídas em 26 gêneros. Eles são predadores de afídeos, coccídeos e outros insetos de corpo macio. Após a publicação das revisões de Hemerobius, Megalomus, Nusalala e Nomerobius ocorreram modificaçôes taxonômicas em nível de gênero e novos registros de distribuição geográfica. O objetivo deste estudo é produzir uma lista das espécies de Hemerobiidae do Brasil e dos espécimes depositados na Coleção de Invertebrados do Instituto Nacional de Pesquisa da Amazônia (INPA), Manaus, Brasil, de forma a sumarizar os dados geográficos das espécies em estados brasileiros e na Região Neotropical e, apresentar novos dados de distribuição geográfica. No INPA existem 19 espécies nominais de Hemerobiidae (55,2\% dos exemplares estudados) de oito gêneros e seis subfamílias; o restante dos espécimes estudados foi identificado em nível genérico. Megalomus marginatus é relatada pela primeira vez para o Brasil e Nusalala dispar para o Equador (Celica). Além disso, dez novos registros para os estados brasileiros são apresentados: dois para Nusalala tessellata e Hemerobius, um para Megalomus impudicus, Notiobiella maculata, Sympherobius ariasi, Megalomus, Nusalala e Sympherobius.

PALAVRAS-CHAVE: Hemerobius, INPA, Megalomus, Nomerobius, Nusalala. 


\section{INTRODUCTION}

Hemerobiidae (Insecta, Neuroptera) is a cosmopolitan clade popularly known as the brown lacewings. They are well known as predators of larvae and adults of small soft-bodied arthropods (Neuenschwander et al. 1975; New 1975) like aphids and coccids, among others (Penny and Monserrat 1983). Presently, there are about 600 described species of hemerobiids, which surely represent only a fraction of extant species, distributed into 26 genera and 10 subfamilies (Oswald 1993, 1994). In the Neotropics there are records of about 100 species (Monserrat 1990, 1996, 1997, 1998, 2000; Oswald 1990) into 14 genera and eight subfamilies (Oswald 1993, 1994; Monserrat and Deretsky 1999). Most of these are species are uncommon and are represented by few individuals in collections.

Catalogues of the Neotropical fauna of Neuroptera were published by Stange (1967) and Penny (1977). Monserrat (1990) published a catalogue of the world fauna of Hemerobiidae and the number of species of these predators in the Neotropics and their distribution have changed significantly. These changes mainly occurred after revisions of Hemerobius L. and Megalomus Rambur from Latin America and of Nusalala Navás of the Neotropics (Monserrat 1996, 1997, 2000) and some isolated papers that reported new records and descriptions of new species. Machado and Martins (2016) summarized the information about the fauna of the Brazilian Hemerobiidae.

Wilson (2002) stated that species are the basic unit of biodiversity. Therefore, strategies for biodiversity conservation should be based on information about species' distributions (Hortal et. al. 2008). A great deal of biological diversity is still waiting to be formally described and cataloged (Whittaker et al. 2005). In addition, there is an inadequate knowledge of living organism distributions at the global (i.e. Linnean shortfall), regional, and even local level, the Wallacean shortfall (Brown and Lomolino 1998; Lomolino 2004). Most taxa require sampling in much of the world and this situation also applies to the Neotropical Hemerobiidae.

The aim of this study was to update a checklist of the Hemerobiidae species from Brazil based on bibliography sources and studied specimens deposited at Coleção de Invertebrados do Instituto Nacional de Pesquisa da Amazônia (INPA), Manaus, Brazil, to present new distributional records for some species, and to summarize the geographical data of species in Brazil and Neotropical regions.

\section{MATERIALS AND METHODS}

The list of species of the Hemerobiidae from Brazil as presented here has been compiled from data resulting from studies published between 1965 and 2016, and from data resulting from a visit of the first author to the INPA Collection, which took place in December 2014 (Table 1).

Observations were made under magnification using a stereomicroscope (MZ 9.5, Leica, Swiss); color images were obtained with a digital camera (DFC 295, Leica, Germany) attached to a stereomicroscope (M205C APO, Leica, Singapore). Serial images from different layers were combined with Helicon Focus software (version 5.3) and figures were prepared using Adobe Photoshop software (version 11.0).

The genitalia were hot-macerated in a $10 \% \mathrm{KOH}$ solution for about 15 minutes and subsequently immersed, for one hour, in a $10 \% \mathrm{C}_{2} \mathrm{H}_{4} \mathrm{O}_{2}$ solution for neutralization. The genitalia structures were studied and stored in glycerin in glass microvials placed on the same pin of the respective specimens. Species identifications were based on Monserrat (1984, 1996, 1997, 2000); Monserrat and Penny (1983) and Oswald (1990, 1993).

In the text, subfamilies, genera and species from Brazil were organized in alphabetical order; related references and collecting sites of Neotropical species were provided. The lists of synonyms were omitted and remitted to available literature.

The following abbreviations related to the names of Brazilian States were used: $\mathrm{AC}=$ Acre, $\mathrm{AM}=$ Amazonas, $\mathrm{BA}=$ Bahia, $\mathrm{DF}=$ Distrito Federal, ES = Espírito Santo, GO = Goiás, MA = Maranhão, $\mathrm{MG}=$ Minas Gerais, $\mathrm{MT}=$ Mato Grosso, $\mathrm{PA}=$ Pará, $\mathrm{PR}=$ Paraná, $\mathrm{RJ}=$ Rio de Janeiro, $\mathrm{RO}=$ Rondônia, $\mathrm{RS}=$ Rio Grande do Sul, SC = Santa Catarina and SP = São Paulo.

The distribution data of the Neotropical species of Hemerobiidae were included in distribution maps prepared with the software DIVA-GIS 7.5.0. The distributions of species in each country and even in Brazilian states are not accurate because most of the studied species did not have geographic coordinate data on the labels.

\section{RESULTS}

In December 2014, there were 230 specimens of Hemerobiidae of six subfamilies, eight genera and nineteen nominal species of Hemerobiidae housed in the INPA Collection (Table 1), including new occurrences in Brazil and Ecuador (indicated by ${ }^{*}$ ) and to Brazilian states $\left(^{* *}\right)$.

The majority (53.0\%) of the specimens housed in the INPA Collection were collected in Chile, followed by Brazil (35.2\%), Ecuador (9.6\%) and the USA (2.2\%).

There are few Hemerobiidae specimens collected in areas of the Brazilian Amazon deposited in the INPA Collection and they correspond to $12.3 \%$ of the total of the material collected at Brazil and $5.6 \%$ of the total of Hemerobiidae specimens deposited there. About $50 \%$ of the total of Brazilian hemerobiids deposited at the INPA Collection is from Nova Teutônia, in the municipality of Seara, in Santa Catarina State. 
Table 1. List of Hemerobiidae (Insecta, Neuroptera) species housed in the Instituto Nacional de Pesquisas da Amazônia Invertebrate Collection (INPA), Manaus, Brazil, in December 2014. AM= Amazonas, $B A=$ Bahia, $G 0=$ Goiás, $M A=$ Maranhão, $M G=$ Minas Gerais, $M T=$ Mato Grosso, $P A=P a r a ́, P R=P a r a n a ́, R J=$ Rio de Janeiro, $\mathrm{RO}=$ Rondônia, $\mathrm{RS}=$ Rio Grande do $\mathrm{Sul}, \mathrm{SC}=$ Santa Catarina and USA = United States of America. * $=$ new record from country; ${ }^{* *}=$ new record from Brazilian states.

\begin{tabular}{|c|c|c|c|}
\hline Subfamily, genus, specie & Author, year & $\mathrm{n}$ & country \\
\hline \multicolumn{4}{|l|}{ Drepanepteryginae } \\
\hline Gayomyia & Banks, 1913 & & \\
\hline G. falcata & (Blanchard, 1851) & 2 & Chile \\
\hline \multicolumn{4}{|l|}{ Hemerobiinae } \\
\hline Hemerobius & Linnaeus, 1758 & & \\
\hline H. bolivari & Banks, 1910 & 30 & Ecuador, Chile, Brazil (PR, SC) \\
\hline H. chilensis & Nakahara, 1965 & 2 & Chile \\
\hline H. tolimensis & Banks, 1910 & 2 & Ecuador \\
\hline Hemerobius sp. & & 41 & USA, Ecuador, Chile, Brazil (AM**, R0, BA**, PR, SC) \\
\hline \multicolumn{4}{|l|}{ Megalominae } \\
\hline Megalomus & Rambur, 1842 & & \\
\hline Me. flinti & (Nakahara, 1965) & 7 & Chile \\
\hline Me. impudicus & (Gerstaecker, 1888) & 20 & Ecuador, Brazil (MG, SC, RS**) \\
\hline Me. marginatus & Banks, 1910 & 1 & Brazil* $^{*}(\mathrm{RS})$ \\
\hline Me. rafaeli & Penny \& Monserrat, 1983 & 1 & Brazil (AM) \\
\hline Me. stangei & González Olazo, 1981 & 2 & Chile \\
\hline Megalomus sp. & & 5 & Chile, Brazil $\left(M A^{* *}, P R\right)$ \\
\hline \multicolumn{4}{|l|}{ Microminae } \\
\hline Micromus & Rambur, 1842 & & \\
\hline Mi. posticus & (Walker, 1853) & 1 & USA \\
\hline Mi. subanticus & (Walker, 1853) & 1 & USA \\
\hline Nusalala & Navás, 1913 & & \\
\hline Nu. dispar & (Banks, 1910) & 4 & Ecuador* \\
\hline Nu. neotropica & (Esben-Petersen, 1914) & 1 & Brazil (SC) \\
\hline Nu. tessellata & (Gerstaecker, 1888) & 27 & Ecuador, Brazil (RO, BA, MT**, GO**, RJ, PR, SC) \\
\hline Nusalala sp. & & 2 & Brazil $\left(M A^{* *}, \mathrm{GO}\right)$ \\
\hline \multicolumn{4}{|l|}{ Notiobiellinae } \\
\hline Notiobiella & Banks, 1909 & & \\
\hline No. maculata & Monserrat \& Penny, 1983 & 3 & Brazil $\left(\mathrm{AM}, \mathrm{PA}^{* *}\right)$ \\
\hline No. paddiae & Monserrat, 1984 & 1 & Brazil (AM) \\
\hline \multicolumn{4}{|l|}{ Sympherobiinae } \\
\hline Nomerobius & Navás, 1916 & & \\
\hline Nom. psychodoides & (Blanchard, 1851) & 3 & Chile \\
\hline Nom. signatus & (Hagen, 1861) & 18 & Chile \\
\hline Nomerobius sp. & & 2 & Chile \\
\hline Sympherobius & Banks, 1904 & & \\
\hline S. ariasi & Penny \& Monserrat, 1983 & 1 & Brazil $(M G * *)$ \\
\hline Sympherobius sp. & & 53 & Chile, Brazil (AM, MA**) \\
\hline
\end{tabular}

\section{DISCUSSION}

The results obtained reveal the incipient nature of knowledge of Hemerobiidae in Brazil, which comprises about $20 \%$ of species of the Neotropical Hemerobiidae. The need is evident for further collection efforts in order to get a good representation of the Brazilian and Amazonian faunas.
In the INPA Collection there are four specimens of Nusalala dispar (Banks, 1910) (Figure 1) that had only been found in Colombia, Hawaii, and Venezuela (Penny 1977; Monserrat 1990, 2000). This study extends the range of $N$. dispar to Ecuador (Celica), about 1,100 km to the southwest in relation to the previous records. The specimens examined in this study match the description of $N$. dispar and are easily 


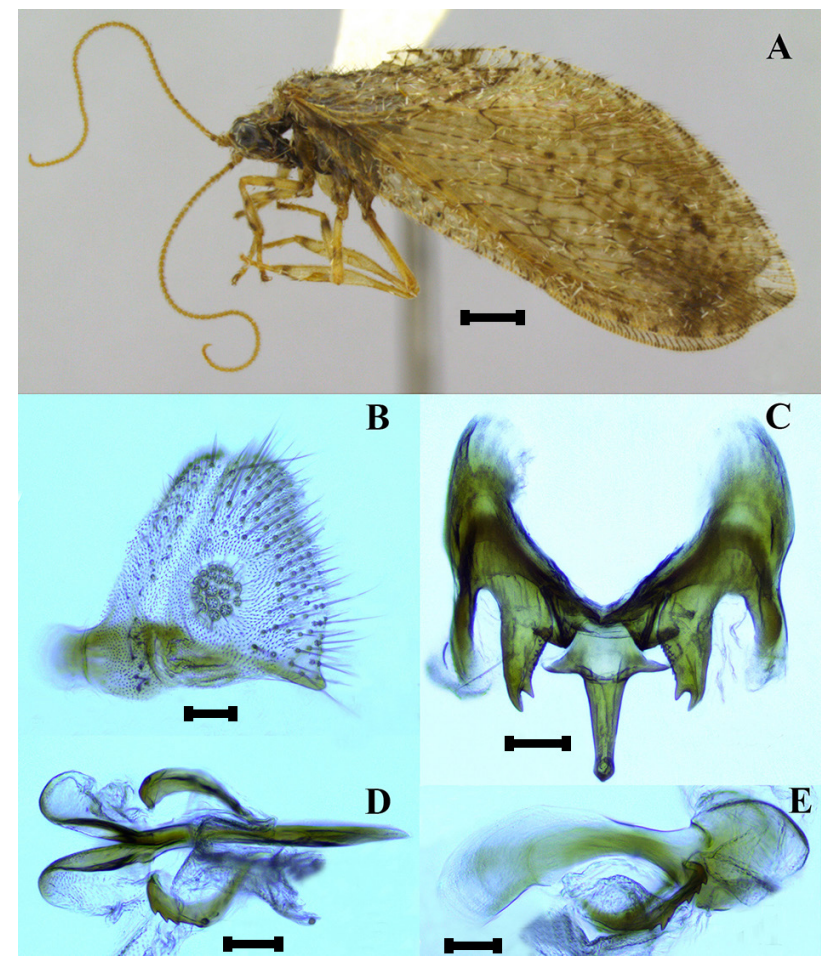

Figure 1. Nusalala dispar (Banks, 1910) (Neuroptera, Hemerobiidae). A. Habitus, scale bar $=1 \mathrm{~mm} ; \mathrm{B}$. Ninth tergite and ectoproct, lateral view; $\mathrm{C}$. Gonarcus, dorsal view; D. Parameres, dorsal view; E. Parameres, lateral view. Scale bar in $B-E=0.1 \mathrm{~mm}$. This figure is in color in the electronic version.

recognized by the morphological characteristics of male terminalia (Figures 1B-E), as described by Monserrat (2000).

The INPA Collection has only one damaged specimen of Megalomus marginatus Banks, 1910 with intact terminalia (Figure 2), collected at Rio Grande do Sul State, Brazil. Previous records indicate that its distribution was restricted to Panama, Colombia and Venezuela (Penny 1977; Monserrat 1990, 1997) and, thus, this finding extends the distribution range of $M$. marginatus to Brazil (RS), about $4,400 \mathrm{~km}$ southeastern of previous records. The terminalia of the studied specimen matches the description of $M$. marginatus and is easily recognized by the morphology of the male ectoproct, gonarcus and parameres (Figures 2B-E), as described by Monserrat (1997).

The specimens of Hemerobius and Sympherobius were identified to the genus level along with some damaged specimens of Nusalala and Megalomus (Table 1). Megalomus, Nusalala, and Sympherobius are reported for the first time in the state of Maranhão and Hemerobius in the states of Amazonas and Bahia; these genera were easily recognized with the identification key proposed by Oswald (1993).

Moreover, five new records for the Brazilian states are presented: Nusalala tessellata (Gerstaecker, 1888) in Mato

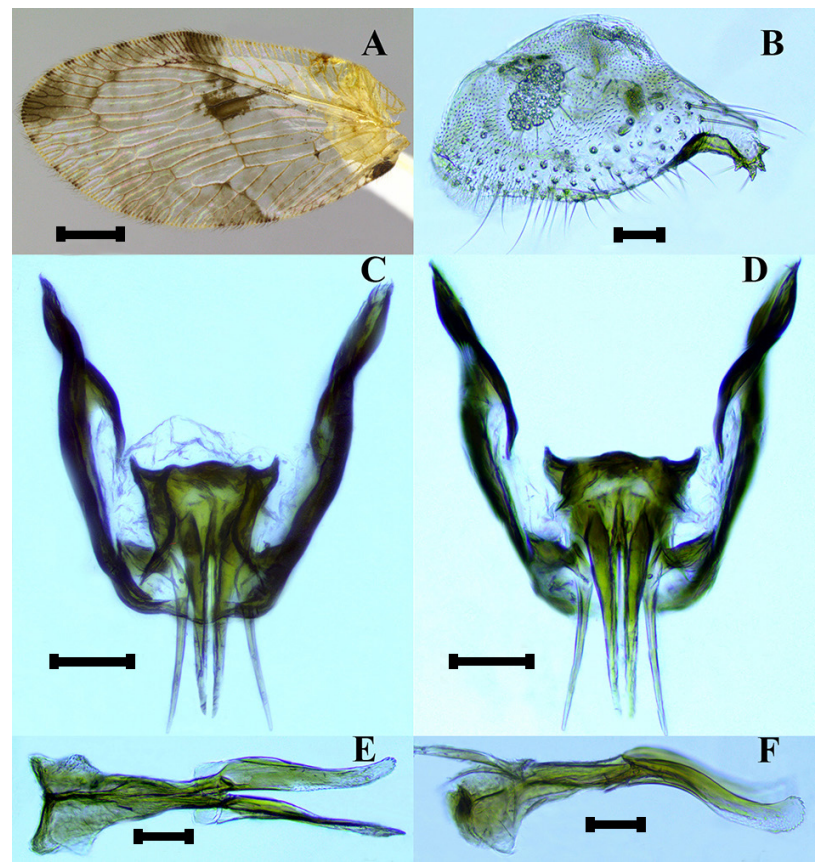

Figure 2. Megalomus marginatus (Gerstaecker, 1888) (Neuroptera, Hemerobiidae). A. Forewing, scale bar $=1 \mathrm{~mm} ; \mathrm{B}$. Ectoproct, lateral view; C. Gonarcus, dorsal view, D. Gonarcus, ventral view; E. Parameres, dorsal view, F. Parameres, lateral view. Scale bar in $B-F=0.1 \mathrm{~mm}$. This figure is in color in the electronic version.

Grosso and Goiás, Megalomus impudicus (Gerstaecker, 1888) in Rio Grande do Sul, Notiobiella maculata Monserrat \& Penny, 1983 in Pará and Sympherobius ariasi Penny \& Monserrat, 1983 in Minas Gerais (Table 1).

The specimens of Nomerobius signatus (Hagen, 1888) (Figure 3) examined in this study were recognized by the shape of the apex of the ninth sternite (Figures 3B-D) and by the anteroventral margin of the male ectoproct (Figure 3B), as described by Oswald (1990). Most of specimens of $N$. signatus showed variation in number and position of microsetae along the shaft and apex of the terminal process of the ninth sternite (Figures 3C-D), which was interpreted as intraspecific variation.

\section{List of species of Hemerobiidae from Brazil}

\section{Subfamily Hemerobiinae}

Hemerobius bolivari Banks, 1910

Synonyms see Monserrat (1996): 447-449. Material examined: see Table 1.

Distribution (Figure 4A). Brazil (RO, DF, MG, SP, RJ, PR, SC, RS), Mexico, Guatemala, Costa Rica, Panama, Colombia, Venezuela, Ecuador, Peru, Bolivia, Chile, Argentina, Paraguay, Uruguay (Penny 1977; Nakahara 1965; 


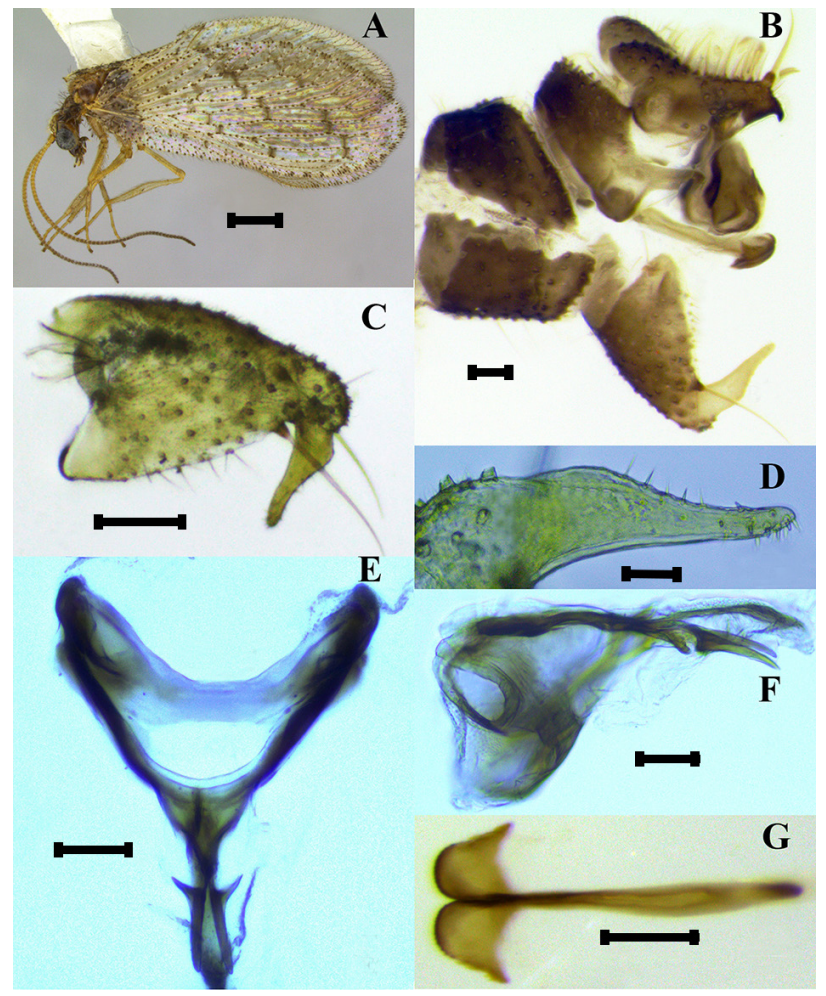

Figure 3. Nomerobius signatus (Hagen, 1888) (Neuroptera, Hemerobiidae). A. Habitus, scale bar $=1 \mathrm{~mm}$; B. Apex of male abdomen, lateral view; C. Ninth sternite, lateral view; $D$. Apex of the terminal process of the ninth sternite, lateral view; E. Gonarcus, dorsal view; F. Gonarcus, lateral view; G. Parameres, dorsal view. Scale bar in $B-G=0.1 \mathrm{~mm}$. This figure is in color in the electronic version.
Penny and Monserrat 1983; Monserrat 1990, 1996, 1998; Lara and Freitas 2003; Lara et al. 2010; Oliveira et al. 2013).

\section{Hemerobius domingensis Banks, 1941}

Distribution (Figure 4A). Brazil (SP, PR), Cuba, Dominican Republic (Penny 1977; Monserrat 1990, 1996; Lara and Freitas 2003).

\section{Hemerobius exceptatus Nakahara, 1965}

Distribution (Figure 4A). Brazil (RJ, SC), Colombia, Venezuela, Peru (Penny 1977; Nakahara 1965; Monserrat 1990, 1996, 1998).

\section{Hemerobius gaitoi Monserrat, 1996}

Distribution (Figure 4A). Brazil (MG, SP, PR, RS), Mexico, Guatemala, Dominican Republic, Costa Rica, Panama, Venezuela, Ecuador (Monserrat 1996, 1998, 2002; Lara and Freitas 2003; Silva et al. 2015).

\section{Hemerobius hernandezi Monserrat, 1996}

Distribution (Figure 4A). Brazil (MG, RS), Mexico, Guatemala, Nicaragua, Costa Rica, Panama, Colombia, Venezuela, Paraguay (Monserrat 1996, 1998, 2002; Silva et al. 2015).

\section{Subfamily Megalominae}

Megalomus impudicus (Gerstaecker, 1888)**

Synonyms see Monserrat (1997): 146-147. Material examined: see Table 1.

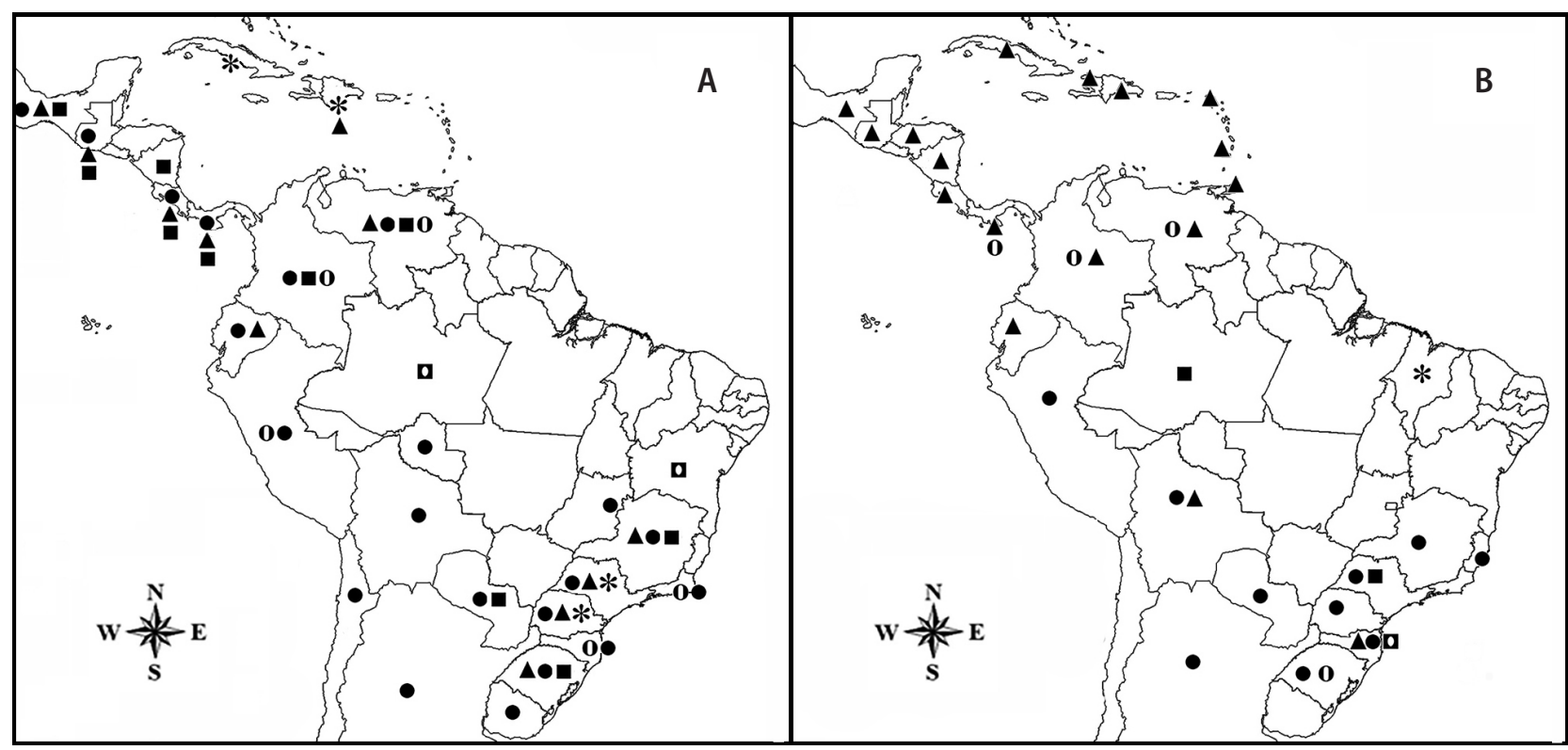

Figure 4. Geographical distribution of the species Hemerobiidae (Neuroptera) recorded to Brazil and their occurrence in the Neotropics. A. Hemerobius bolivari Banks, $1910(\bullet)$, Hemerobius domingensis Banks, $1941\left(^{*}\right)$, Hemerobius exceptatus Nakahara, $1965\left({ }^{\circ}\right)$, Hemerobius gaitoi Monserrat, $1996(\boldsymbol{\star})$, Hemerobius hernandezi Monserrat, 1996 (•) and Hemerobius sp. (); B. Megalomus impudicus (Gerstaecker, 1888) (•), Megalomus marginatus Banks, $1910\left({ }^{\circ}\right)$, Megalomus minor Banks, 1905 (^), Megalomus rafaeli Penny \& Monserrat, 1983 (־), Megalomus ricoi Monserrat, 1997 (); and Megalomus sp. (*). 
Distribution (Figure 4B). Brazil (MG, ES, SP, PR, SC, RS), Peru, Bolivia, Argentina, Paraguay (Penny 1977; Monserrat 1990, 1997; Lara et al. 2010; Oliveira et al. 2013). Remarks: This note extends the distribution range of Megalomus impudicus to Rio Grande do Sul State, Brazil.

\section{Megalomus marginatus Banks, 1910*}

Material examined: see Table 1 and Figure 2.

Distribution (Figure 4B). Brazil (RS), Panama, Colombia,Venezuela (Penny 1977; Monserrat 1990, 1997). Remarks: This note extends the distribution range of Megalomus marginatus to Brazil (RS), about 4,400 km to the southeast from the previous records.

Megalomus minor Banks, 1905

Synonyms see Monserrat (1997): 149-150.

Distribution (Figure 4B). Brazil (SC), Mexico, Cuba, Haiti, Dominican Republic, Guatemala, Honduras, Nicaragua, Saint Vincent and Grenadines, Trinidad \& Tobago, West Indies, Costa Rica, Panama, Colombia, Venezuela, Ecuador, Bolivia (Penny 1977; Monserrat 1990, 1997, 2002).

Megalomus rafaeli Penny \& Monserrat, 1983

Material examined: see Table 1.

Distribution (Figure 4B). Brazil (AM, SP) (Penny and Monserrat 1983; Monserrat 1997; Lara et al. 2010).

Megalomus ricoi Monserrat, 1997
Distribution (Figure 4B). Brazil (SC) (Monserrat 1997).

\section{Subfamily Microminae}

\section{Nusalala erecta Navás, 1913}

Synonyms see Monserrat (2000): 120.

Distribution (Figure 5A). Brazil (was not possible find the state(s)), Ecuador, Peru, Argentina, Paraguay (Penny 1977; Monserrat 1990, 2000, 2002, 2004).

Nusalala ilusionata Monserrat, 2004

Distribution (Figure 5A). Brazil (PR, RS) (Monserrat 1990, 2000, 2004).

Nusalala neotropica (Esben-Petersen, 1914)

Synonyms see Monserrat (2000): 99. Material examined: see Table 1 and Figure 1.

Distribution (Figure 5A). Brazil (BA, RJ, SC), Colombia, Venezuela, Ecuador, Peru, Bolivia, Argentina, Paraguay (Penny 1977; Monserrat 1990, 2000).

Nusalala tessellata (Gerstaecker, 1888)**

Synonyms see Monserrat (2000): 115-116. Material examined: see Table 1 .

Distribution (Figure 5A). Brazil (RO, MT, GO, DF, MG, ES, SP, RJ, PR, SC, RS), Mexico, Guatemala, Dominica, Porto Rico, British Virgin Islands, Trinidad \& Tobago, Honduras, Costa Rica, Panama, Colombia, Venezuela, Ecuador, Peru, Bolivia, Paraguay, Argentina (Penny 1977;

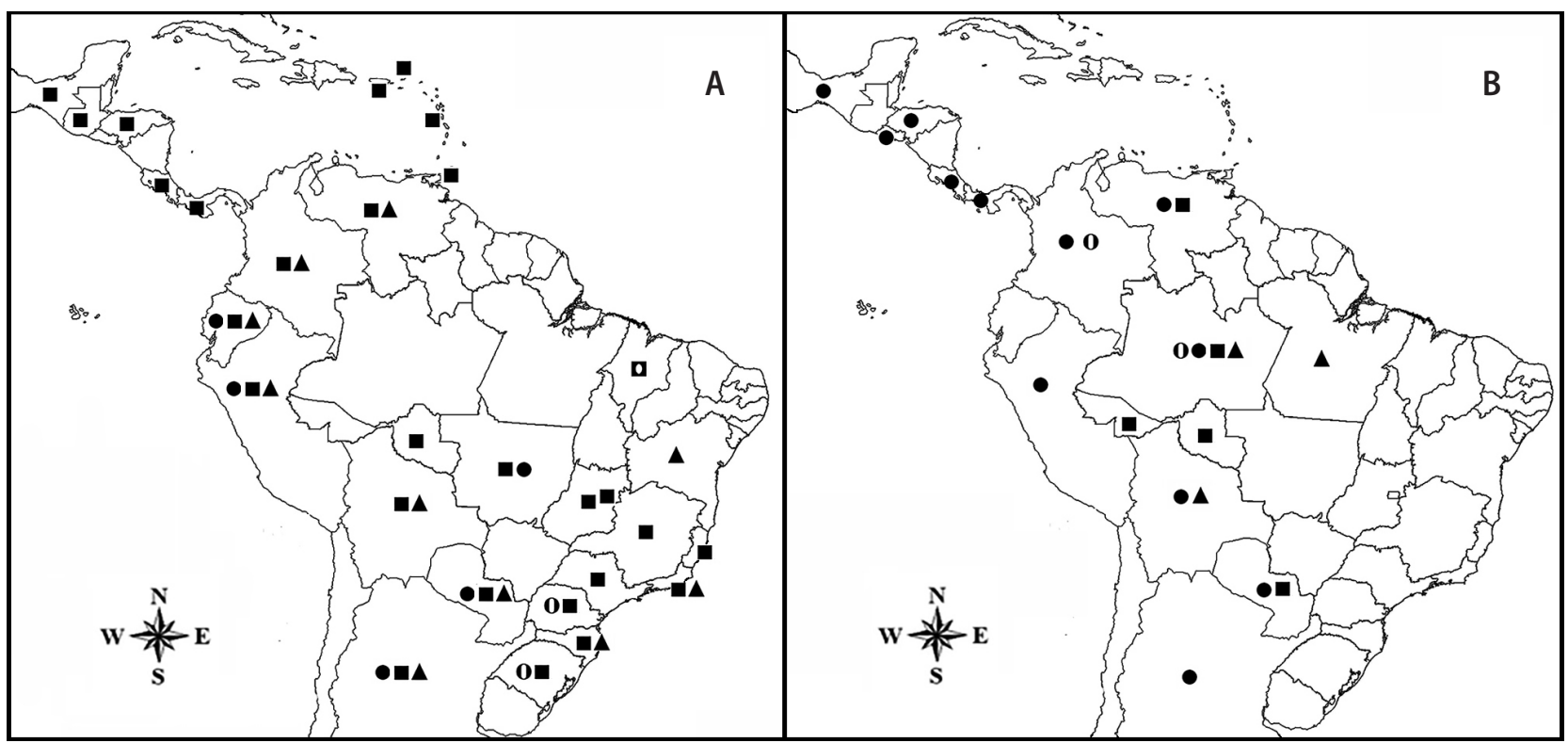

Figure 5. Geographical distribution of the species Hemerobiidae (Neuroptera) recorded to Brazil and their occurrence in the Neotropics. A. Nusalala erecta Navás, $1913(\bullet)$, Nusalala ilusionata Monserrat, $2004\left(^{\circ}\right)$, Nusalala neotropica (Esben-Petersen, 1914), (^), Nusalala tessellata (Gerstaecker, 1888) (•) and Nusalala sp. (); B. Notiobiella brasiliensis Monserrat \& Penny, $1983\left({ }^{\circ}\right)$, Notiobiella cixiiformis (Gerstaecker, 1888) $(\bullet)$, Notiobiella maculata Monserrat \& Penny, 1983 (^) and Notiobiella paddiae Monserrat, 1984 ("). 
Monserrat 1990, 2000, 2002, 2004; Penny and Monserrat 1983; Lara and Freitas 2002; Lara et al. 2010; Oliveira et al. 2013). Remarks: This note extends the distribution range of Nusalala tessellata to Mato Grosso and Goiás States, Brazil.

\section{Subfamily Notiobiellinae}

Notiobiella brasiliensis Monserrat \& Penny, 1983

Distribution (Figure 5B). Brazil (AM), Colombia (Monserrat and Penny 1983; Penny and Monserrat 1983; Monserrat 1990).

Notiobiella cixiiformis (Gerstaecker, 1888)

Synonyms see Monserrat (1984): 89 and Monserrat (1996): 404.

Distribution (Figure 5B). Brazil (AM), Mexico, El Salvador, Honduras, Costa Rica, Panama, Colombia, Venezuela, Peru, Bolivia, Argentina, Paraguay (Nakahara 1965, Penny 1977; Monserrat and Penny 1983; Monserrat 1984, 1990, 1998, 2002; González Olazo 1992).

Notiobiella maculata Monserrat \& Penny, 1983**

Material examined: see Table 1.

Distribution (Figure 5B). Brazil (AM, PA), Bolivia (Monserrat and Penny 1983; Penny and Monserrat 1983; Monserrat 1990, 1998). Remarks: This note extends the distribution range of Notiobiella maculata to Pará State, Brazil.

Notiobiella paddiae Monserrat, 1984

Material examined: see Table 1.

Distribution (Figure 5B). Brazil (AM, AC, RO), Venezuela, Paraguay (Monserrat and Penny 1983; Penny and Monserrat 1983; Monserrat 1984, 1990).

\section{Subfamily Sympherobiinae}

Nomerobius psychodoides (Blanchard, 1851)

Synonyms see Oswald (1990): 21. Material examined: see Table 1.

Distribution (Figure 6). Brazil (PA, SP), Peru, Chile, Argentina, Uruguay (Nakahara 1965; Penny 1977; Penny and Monserrat 1983; Monserrat 1990, 1998, 2003, 2008; Oswald 1990; González Olazo 1992; Lara et al. 2010).

Sympherobius amazonicus Penny \& Monserrat, 1983

Distribution (Figure 6). Brazil (AM) (Penny and Monserrat 1983; Monserrat 1990).

Sympherobius ariasi Penny \& Monserrat, 1983**

Material examined: see Table 1.

Distribution (Figure 6). Brazil (AM, PA, MG, SP) (Penny and Monserrat 1983; Monserrat 1990). Remarks: This note extends the distribution range of Sympherobius ariasi to Minas Gerais State, Brazil.

Sympherobius gayi Navás, 1910

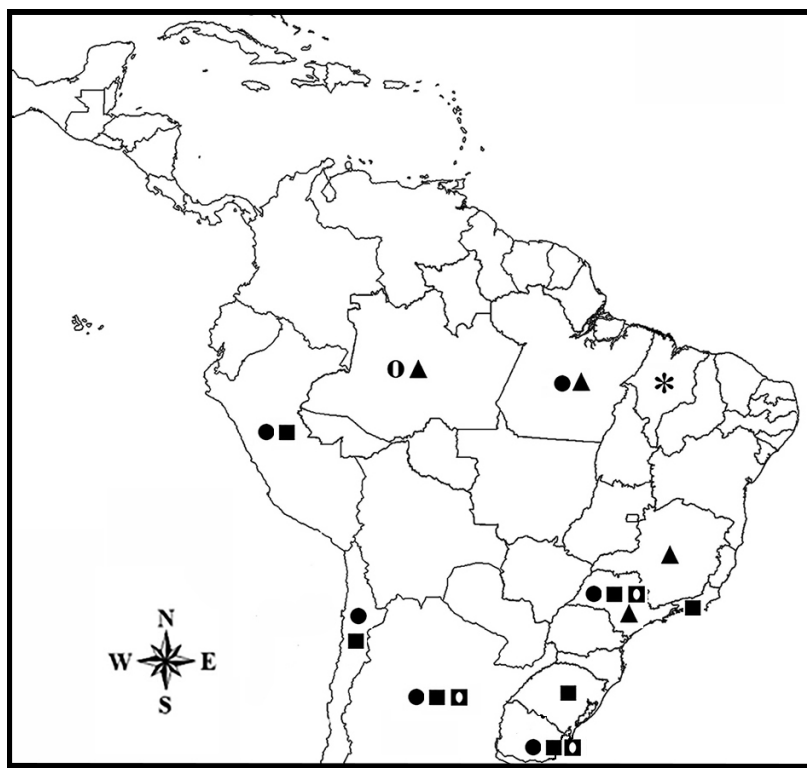

Figure 6. Geographical distribution of the species Nomerobius psychodoides (Blanchard, 1851), Sympherobius amazonicus Penny \& Monserrat, $1983\left(^{\circ}\right)$, Sympherobius ariasi Penny \& Monserrat, 1983 (^), Sympherobius gayi Navás, 1910 ("), Sympherobius mirandus Navás, 1920 (') and Sympherobius sp. $\left(^{*}\right)$ recorded to Brazil and their occurrence in the Neotropics.

Synonyms see Monserrat (1998): 131-132.

Distribution (Figure 6). Brazil (SP, RJ, RS), Peru, Chile, Argentina, Uruguay (Nakahara 1965; Penny 1977; Monserrat 1990, 1998, 2003, 2008; Monserrat and Deretsky 1999).

Sympherobius mirandus (Navás, 1920)

Synonyms see Monserrat (1990): 237.

Distribution (Figure 6). Brazil (SP), Argentina, Uruguay (Penny 1977; Monserrat 1990, 1998, 2008; Lara and Perioto 2003; Lara et al. 2010).

\section{CONCLUSIONS}

This checklist contributes to expansion and summarization of knowledge of the Hemerobiidae fauna from Brazil. The data presented here indicate that, for the hemerobiids, it is necessary to expand the collection efforts to improve its representativeness in Brazilian collections.

\section{ACKNOWLEDGEMENTS}

The authors are grateful to the Fundação de Amparo à Pesquisa do Estado do Amazonas (Edital no 011/2013 Coleçôes Biológicas) for financial support.

\section{REFERENCES}

Brown, J.H.; Lomolino, M.V. 1998. Biogeography. 2nd ed. Sinauer Press, Sunderland, Massachusetts, 691p. 
González Olazo, E.V. 1992. Una nueva especie de Nomerobius (Neuroptera, Hemerobiidae) de la Argentina. Acta Zoológica Lilloana, 42: 215-224.

Hortal, J.; Jiménez-Valverde, A.; Gómez, J.F.; Lobo, J.M.; Baselga, A. 2008. Historical bias in biodiversity inventories affects the observed environmental niche of the species. Oikos, 117: 847-858.

Lara, R.I.R.; Freitas, S. 2002. Caracterização morfológica de adultos de Nusalala tessellata (Gerstaecker, 1888) (Neuroptera, Hemerobiidae). Revista Brasileira de Entomologia, 46: 523-530.

Lara, R.I.R.; Freitas, S. 2003. Caracterização morfológica de espécies de Hemerobius Linnaeus, 1758 (Neuroptera, Hemerobiidae) associadas a cultivo de café (Coffea arabica L.), milho (Zea mays L.) e erva-mate (Ilex paraguariensis St. Hill.). Revista Brasileira de Entomologia, 47: 427-434.

Lara, R.I.R.; Perioto, N.W. 2003. Primeiro registro de ocorrência de Sympherobius miranda (Navás, 1920) (Neuroptera, Hemerobiidae) para o Brasil. Arquivos do Instituto Biológico, 70: 511-512.

Lara, R.I.R.; Perioto, N.W.; Freitas, S. 2010. Diversidade de hemerobiídeos (Neuroptera) e suas associaçôes com presas em cafeeiros. Pesquisa Agropecuária Brasileira, 45: 115-123.

Lomolino, M.V. 2004. Conservation biogeography. In: Lomolino, M.V.; Heaney, L.R. (Ed.). Frontiers of biogeography: new directions in the geography of nature. Sinauer Associates, Sunderland, p. 293-296.

Machado, R.J.C.; Martins, C.C. 2016. Hemerobiidae. In: Catálogo Taxonômico da Fauna do Brasil. (http://fauna.jbrj.gov.br/fauna/ listaBrasil/ConsultaPublicaUC/ConsultaPublicaUC.do). Accessed on $03 / 05 / 2016$.

Monserrat, V.J. 1984. Sobre las especies americanas del genero Notiobiella Banks, 1909, I (Neuroptera, Planipennia, Hemerobiidae). In: Gepp, J.; Aspöck, H.; Hölzel, H. (Ed.). Progress in World's Neuropterology. Institut für Umweltwissenschaften und Naturschutz Österreichischen Akademie der Wissenschaften, Graz, p. 85-97.

Monserrat, V.J. 1990. A systematic checklist of the Hemerobiidae of the world (Insecta: Neuroptera). In: Mansell, M.W.; Aspöck H. (Ed.). Advances in Neuropterology, Proceedings of the Third International Symposium on NeuropterologySouth African Department of Agricultural Development, Pretoria, p. 215-262.

Monserrat, V.J. 1996. Revision del genero Hemerobius de Latinoamerica (Neuroptera, Hemerobiidae). Fragmenta Entomologica, 27: 399-523.

Monserrat, V.J. 1997. Revisión del genero Megalomus de Latinoamerica (Neuroptera, Hemerobiidae). Fragmenta Entomologica, 29: 123-206.

Monserrat, V.J. 1998. Nuevos datos sobre los hemeróbidos de América (Neuroptera: Hemerobiidae). Journal of Neuropterology, 1: 109-153.

Monserrat, V.J. 2000. Revisión del género Nusalala (Neuroptera, Hemerobiidae). Fragmenta Entomologica, 32: 83-162.

Monserrat, V.J. 2002. Family Hemerobiidae. In: Penny, N.D. (Ed.). A guide to the lacewings (Neuroptera) of Costa Rica. Proceedings of the California Academy of Sciences, 53: 238-251.

Monserrat, V.J. 2003. Contribución al conocimiento de los hemeróbidos de Patagonia y Tierra del Fuego (Insecta, Neuroptera, Hemerobiidae). Graellsia, 59: 37-56.
Monserrat, V.J. 2004. Nuevos datos sobre algunas especies de hemeróbidos (Insecta: Neuroptera: Hemerobiidae). Heteropterus Revista de Entomología, 4: 1-26.

Monserrat, V.J. 2008. Nuevos datos sobre algunas especies de hemeróbidos (Insecta, Neuroptera, Hemerobiidae). Graellsia, 64: 233-253.

Monserrat, V.J.; Penny, N.D. 1983. Sobre las especies americanas del genero Notiobiella Banks, 1909, II (Neuroptera, Planipennia, Hemerobiidae). Nouvelle Revue d'Entomologie, 13: 125-132.

Monserrat, V.J.; Deretsky, Z. 1999. New faunistical, taxonomic and systematic data on brown lacewings (Neuroptera: Hemerobiidae). Journal of Neuropterology, 2: 45-66.

Nakahara, W. 1965. Neotropical Hemerobiidae in the United States National Museum. Proceedings of the United States National Museum, 117: $107-122$

Neuenschwander, P.; Hagen, K.S.; Smith, R.F. 1975. Prédation on aphids in California’s alfalfa fields. Hilgardia, 43: 53-78.

New, T.R. 1975. The biology of Chrysopidae and Hemerobiidae (Neuroptera) with reference to their usage as biocontrol agents: a review. Transactions of the Royal Entomological Society of London, 127: $115-140$

Oliveira, R.C.; Lara, R.I.R.; Fonseca, A.R.; Perioto, N.W. 2013. Hemerobiidae (Neuroptera) in the midwestern region of Minas Gerais State, Brazil. Revista Colombiana de Entomología, 39: 256259.

Oswald, J.D. 1990. Revision of the Neotropical brown lacewing genus Nomerobius (Neuroptera, Hemerobiidae). Annals of the Entomological Society of America, 83: 18-29.

Oswald, J.D. 1993. Revision and cladistic analysis of the world genera of the family Hemerobiidae (Insecta: Neuroptera). Journal of the New York Entomological Society, 101: 143-299.

Oswald, J.D. 1994. A new phylogenetically basal subfamily of brown lacewings from Chile (Neuroptera, Hemerobiidae). Entomologica Scandinavica, 25: 295-302.

Penny, N.D. 1977. Lista de Megaloptera, Neuroptera e Raphidioptera do México, América Central, Ilhas Caraíbas e América do Sul. Acta Amazonica, 7: 5-61.

Penny, N.D.; V.J. Monserrat. 1983. Neuroptera of the Amazon basin Part 10-Hemerobiidae. Acta Amazonica, 13: 879-909.

Silva, M.; Lara, R.I.R.; Souza. B. 2015. Primeiro registro de ocorrência de Hemerobius gaitoi Monserrat, 1996 e Hemerobius hernandezi Monserrat, 1996 (Neuroptera: Hemerobiidae) para o estado de Minas Gerais, Brasil. Arquivos do Instituto Biológico, 82: 1-3.

Stange, L.A. 1967. Catálogo de Neuroptera de Argentina y Uruguay. Acta Zoologica Lilloana, 22: 5-88.

Whittaker, R.J.; Araújo, M.B.; Paul, J.; Ladle, R.J.; Watson, J.E.M.; Willis, K.J. 2005. Conservation biogeography: assessment and prospect. Diversity and Distributions, 11: 3-23.

Wilson, E.O. 2002. The future of life. Alfred A. Knopf, New York, 256p.

Recebido em 05/04/2016

Aceito em 09/06/2016 